\title{
PREVALENCE OF PSORIASIS IN POLYARTHRITIC PATIENTS AND THEIR RELATIVES
}

BY

\author{
HARVEY BAKER \\ The London Hospital
}

The assertion that psoriatic arthritis (P.A.) is an entity distinct from rheumatoid arthritis (R.A.) rests on serological, clinical, and epidemiological evidence. This paper is concerned with the last of this triad, the area in which the evidence has been least convincing.

Do psoriasis and inflammatory polyarthritis of any type occur together more often than chance alone would dictate? The published evidence on the prevalence of psoriasis in patients with R.A. when last comprehensively reviewed by Gribble (1955) seemed to indicate that between 2.5 and 5 per cent. of such arthritics had psoriasis as opposed to 1 to 2 per cent. of the population at large. Gribble also showed that there was no satisfactory data on the converse problem, the prevalence of R.A. in psoriatics, published estimates varying between 0.5 and 32 per cent.

In the past decade two important advances relevant to this problem have been made: the introduction of serological methods in the study of arthritis, and the use of the American Rheumatism Association criteria which have made more meaningful the comparison of epidemiological data obtained at different centres. Since the studies analysed by Gribble were made without the benefit of these advances, it was thought worthwhile to re-examine these problems.

The first object of this study has been to determine the prevalence of psoriasis in samples of the following groups of hospital patients:

(1) Those with sero-positive rheumatoid arthritis.

(2) Those with a sero-negative polyarthritis in whom no diagnosis other than R.A. or P.A. could be made.

(3) A control series.

Since the predisposition to psoriasis is known to be inherited (Steinberg, Becker, Fitzpatrick, and
Kierland, 1951), the second object was to determine whether a latent psoriatic genetic trait could be one of the factors responsible for the development of sero-negative R.A. or for the continued seronegativity of some arthritic patients in the presence of advancing disease of rheumatoid pattern. No means of detecting latent psoriasis is known, but the significant presence of the trait in some of a group of arthritic subjects could be inferred if psoriasis were found in their close relatives more often than in a control group or the population at large. In the second part of this study this possibility was investigated further by comparing the prevalence of psoriasis in the following groups:

(4) The siblings of patients with sero-negative R.A. (who themselves had never had psoriasis).

(5) The siblings of patients with sero-positive R.A.

\section{Material and Methods}

The source of arthritic patients for study was the diagnostic index of the Department of Physical Medicine and Rheumatology at the London Hospital. It was found that eight compartments of this index might contain patients with inflammatory polyarthritis (ankylosing spondylitis, Reiter's syndrome, etc., being excluded). These compartments were examined for the years 19551964 , and the notes of 1,885 patients were perused. 630 of these patients appeared to satisfy the criteria below and were approached by letter.

Patients Examined.-397 were examined and a sheep cell agglutination test (S.C.A.T.) was performed by the author. 55 of these proved not to satisfy the criteria and were discarded; in 26 of these the reasons were serological -either because both S.C.A.T. and latex tests were border line (six cases) or because of disparity between the results of the two tests (the remainder). Of the 342 remaining cases, 246 formed the series designated "examined sero-positive arthritic propositi" and 96 formed the series designated "examined sero-negative arthritic propositi". Of the 246 sero-positive patients, 
38 were included on the basis of previous positive S.C.A.T. and latex tests, the author's S.C.A.T. being negative. These were largely burned-out cases of rheumatoid arthritis. 25 patients, previously sero-negative, were found on retesting to have a positive S.C.A.T. and were included in the sero-positive group if the appropriate criteria were satisfied.

Patients not Examined.-The 233 patients who were not seen had died, defaulted from the care of the hospital, or failed to co-operate. From perusal of their notes, 199 satisfied the criteria for admission to one or other series. 162 formed the series designated "non-examined seropositive arthritic propositi", and 37 the series designated "non-examined sero-negative arthritic propositi". The serological data in the remaining 34 were inadequate for classification.

Criteria for admission to the two series were essentially those laid down by the A.R.A., slightly modified as indicated in Appendix I.

In all the examined propositi, the diagnosis of psoriasis was made by the author. Before this work, two small "observer variability" studies were made in which departmental colleagues co-operated and which resulted in certain criteria being drawn up for border-line cases (see Appendix II).

Controls.-Patients admitted to the surgical beds of the hospital were used for the control series. The surgical wards were examined in blocks, periodically, according to a pre-arranged schedule. Patients were admitted to the series in groups by age and sex, the size of the control group of siblings being expanded as sero-positive arthritic propositi were accumulated, three controls (matched for age and sex) being seen for each examined sero-positive propositus. In this way, 738 control patients were seen.

S.C.A.T. were performed using a standard method which, with minor modifications, was that of Ball (1950).

For the family study an arbitrary area covered by the A-Z map of London was designated as the "inner area" and examination of all siblings in the area was attempted. Questionnaires were sent to all siblings in an "outer area" (the rest of the world). A few siblings from the "outer area" presented themselves for examination, not surprisingly including a few with psoriasis. The age distribution of the two groups of propositi was comparable as were their social class and religion.

All propositi with any suggestion of past or present psoriasis were excluded from this part of the study. 47 sero-negative propositi who had live siblings whose whereabouts were known were used, and these had $133 \vec{\omega}$ living siblings; the names and addresses of 120 were obtained, 68 living in the "inner area" and 52 in the 승 "outer area".

130 sero-positive propositi were used, and these had of 444 live siblings; the addresses of 403 were obtained, 241 i living in the "inner area" and 162 in the "outer area". N

\section{Results}

\section{Psoriasis in the Propositi}

The prevalence rates for psoriasis in the two groups of arthritic propositi and controls are shown in Table I. Crude and corrected rates are given, the latter after removal from consideration of those patients referred indirectly to the Rheumatology Department by the Skin Department because they had psoriasis and arthritis. Such referrals, which were numerous in the sero-negative group, clearly caused a sampling error.

Increased willingness on the part of arthritics with psoriasis to participate in this study certainly loaded the number of psoriatics found by examination,

TABLE I

PREVALENCE OF PSORIASIS IN ARTHRITIC PROPOSITI AND CONTROLS

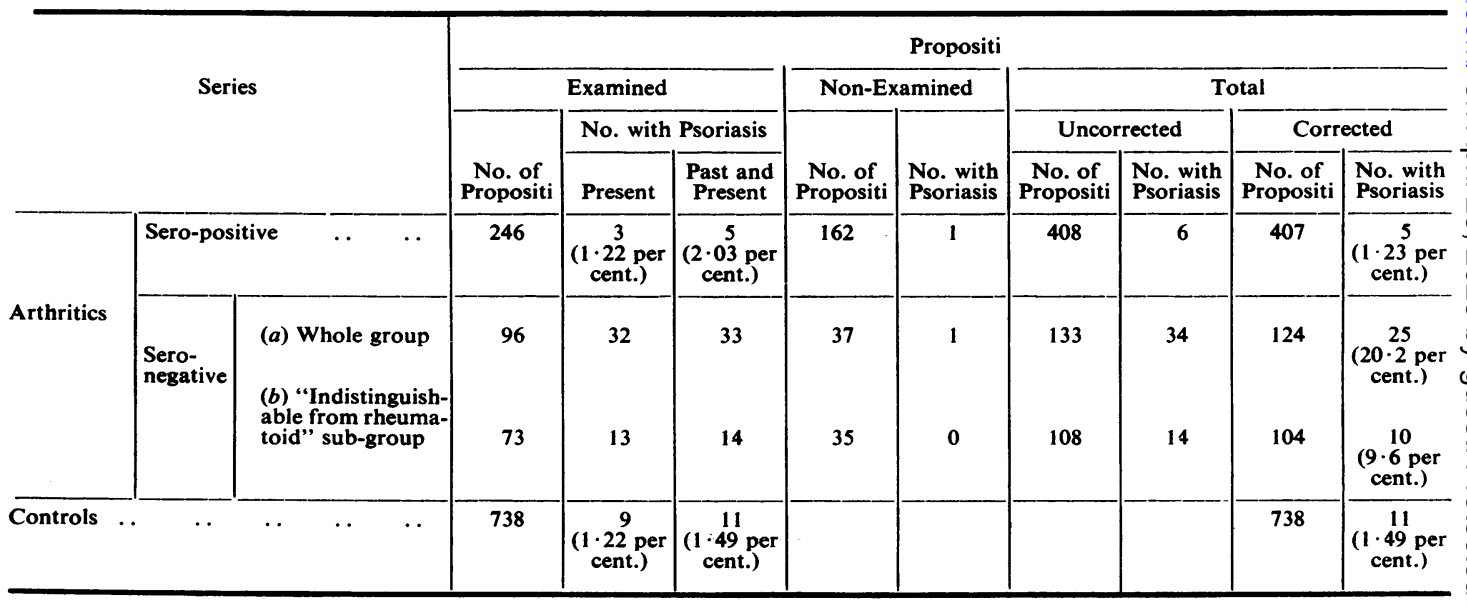


since psoriasis was mentioned in the letter to propositi, but this would not have affected the total rate in the combined groups of examined and nonexamined propositi.

Since it would have begged the question to exclude patients with psoriasis and any particular pattern of arthritis, many patients with "classical psoriatic arthritis" were included in the seronegative group since they satisfied the diagnostic criteria. Psoriatic prevalence rates have therefore been given for the whole group of sero-negative propositi and for the sub-group with a joint disease indistinguishable from rheumatoid arthritis from which patients with well-recognized psoriatic patterns of joint involvement have been excluded.

Had the serological status of the arthritic propositi been ignored, thirty psoriatics would have been found in 531 patients (corrected totals), i.e. 5.6 per cent., a rate comparable to that previously reported (Gribble, 1955).

\section{Psoriasis in the Siblings}

These findings are shown in Table II. The "inner area" examination completion rates for the two samples are seen to be 61/68 (90 per cent.) and 215/ 241 (89 per cent.). Correcting for the likely distribution of the siblings whose whereabouts were unknown gives completion rates of 82 and 84 per cent. respectively.

Combining the data obtained by examination and questionnaire for both the inner and outer areas yields six psoriatics amongst 96 siblings $(6 \cdot 2$ per cent.) in the sero-negative group and five psoriatics amongst 356 siblings (1.4 per cent.) in the seropositive group.

\section{Summary of Results}

The prevalence of psoriasis in patients with seropositive rheumatoid arthritis (found to be between
$1 \cdot 22$ and 2 per cent.) is clearly of the same order as that in the control subjects ( 1.49 per cent.).

A significantly increased prevalence of psoriasis was found in patients with sero-negative polyarthritis (20 per cent.). When subjects in this group with a pattern of joint disease characteristically seen in psoriatics were removed from consideration, 9.6 per cent. of the remainder-those with a disease clinically indistinguishable from sero-positive R.A. had psoriasis, a rate at least five times as high as in the sero-positive and control propositi $(P<0.01)$.

The prevalence of psoriasis in the siblings of patients with sero-positive R.A. was 1.4 per cent., of the same order as in the sero-positive propositi themselves and the control subjects.

The prevalence of psoriasis in the siblings of the sero-negative propositi was $6 \cdot 2$ per cent., over four times higher than in the siblings of the sero-positive propositi.

\section{Discussion}

This study has led primarily to the accumulation of data on the prevalence of psoriasis in patients with polyarthritis, in their siblings, and in control subjects without arthritis. The rates so obtained can only be validly contrasted if the respective groups of propositi are comparable in other respects.

The selection of cases from a hospital diagnostic index presented problems. Many patients labelled "R.A." in the index had not enough data recorded in their notes to warrant inclusion. This lack of documentation might have been less likely to occur in patients with obvious psoriasis, "P.A." being perhaps of more interest than "ordinary R.A." in a busy clinic. Secondly, the mention of psoriasis in the initial letter of inquiry sent to 630 patients undoubtedly selectively attracted the interest of those with psoriasis. Nothing could be done to

TABLE II

PREVALENCE OF PSORIASIS IN SIBLINGS OF PROPOSITI WITH POLYARTHRITIS

\begin{tabular}{|c|c|c|c|c|c|c|c|c|}
\hline & & & & & \multicolumn{4}{|c|}{ Propositi } \\
\hline \multirow{2}{*}{\multicolumn{5}{|c|}{ Area }} & \multicolumn{2}{|c|}{ Sero-negative } & \multicolumn{2}{|c|}{ Sero-positive } \\
\hline & & & & & No. of Siblings & No. with Psoriasis & No. of Siblings & No. with Psoriasis \\
\hline \multirow[t]{2}{*}{ Inner } & $\begin{array}{l}\text { Examination } \\
\text { Questionnaire } \\
\text { History . } \\
\text { No Information }\end{array}$ & $\begin{array}{l}\because \\
\because \\
\cdots \\
\end{array}$ & $\begin{array}{l}\ldots \\
\cdots \\
\cdots\end{array}$ & $\begin{array}{l}\ldots \\
\cdots \\
\cdots\end{array}$ & $\begin{array}{r}61 \\
1 \\
4 \\
2 \\
\end{array}$ & $\begin{array}{l}\mathbf{3} \\
\mathbf{0} \\
\mathbf{0} \\
\mathbf{0} \\
\end{array}$ & $\begin{array}{r}215 \\
8 \\
5 \\
13 \\
\end{array}$ & $\begin{array}{l}3 \\
\mathbf{0} \\
\mathbf{0} \\
\mathbf{0} \\
\end{array}$ \\
\hline & Total &. &.. & $\therefore$ & 68 & 3 & 241 & 3 \\
\hline \multirow[t]{2}{*}{ Outer } & $\begin{array}{l}\text { Examination } \\
\text { Questionnaire } \\
\text { History } \\
\text { No Information } \\
\end{array}$ & $\begin{array}{l}. . \\
\because \\
\cdots\end{array}$ & $\begin{array}{l}. . \\
\cdots \\
\cdots\end{array}$ & $\because$. & $\begin{array}{r}4 \\
30 \\
5 \\
13 \\
\end{array}$ & $\begin{array}{l}2 \\
1 \\
0 \\
0\end{array}$ & $\begin{array}{r}128 \\
8 \\
21 \\
\end{array}$ & $\begin{array}{l}1 \\
1 \\
0 \\
0 \\
\end{array}$ \\
\hline & Total & $\ldots$ & .. & . & 52 & 3 & 162 & 2 \\
\hline
\end{tabular}


correct the first of these factors. The second was corrected by calculating the minimal prevalence of psoriasis in the combined groups of "examined" and "non-examined" propositi. In the family study only siblings were used (too many parents of this age group were dead and too many children were young enough not to have manifested a psoriatic tendency.) The high examination completion rate $(>80$ per cent.) should have excluded any bias due to psoriatic siblings making themselves selectively available for examination. Refusal to co-operate in giving addresses of siblings, though less likely to occur if psoriasis were known to affect the family concerned, was encountered so rarely as not to influence the results.

Surgical in-patients were used as control subjects, it being thought that, within the hospital population, they were the least likely to show selective concentration or dilution of psoriasis. Psoriasis is not a contraindication to necessary surgery. Exacerbation of existing psoriasis might be caused by the stress of hospital admission and operation, but the disease is rarely initiated by such factors and in any case this could only happen once in the lifetime of each potential psoriatic. The argument that such factors influence the prevalence of total past and present psoriasis can therefore be dismissed.

Essentially, this study has been concerned with the relationship between the presence or otherwise of serum rheumatoid factor and psoriasis. The criteria of sero-positivity and sero-negativity (see Appendix I) were necessarily arbitrary, and six otherwise suitable propositi with persistently "border-line" S.C.A.T. and latex tests were excluded; only one of these had psoriasis. It is well known that a rheumatoid patient may not become seropositive until many years after the onset of the disease (Dixon, 1960). The chosen minimum acceptable length of history for the sero-negative propositi ( 2 years) was arbitrary; use of a shorter period would have resulted in too many potentially sero-positive arthritics being included, a longer period in an inadequate number of sero-negative propositi for study.

The use of hospital patients rather than population samples for this sort of study is fraught with hazards of selection. In general, sero-negative "R.A." tends to be a milder disease than the seropositive variety, and cases of sero-negative "R.A." reaching hospital are likely to be drawn from the more severe end of the spectrum. If psoriasis were, in fact, associated more commonly with severe rather than mild polyarthritis, this would tend to increase the observed prevalence in the sero-negative group, but it is not established that this is so. 3 Patients with two diseases may also be more likely to reach hospital than those with one, but the poten-? tial effect of this factor was reduced here by removing $\stackrel{\vec{S}}{\overrightarrow{2}}$ from consideration patients referred indirectly fromthe Skin Department.

The findings of this study support the contention $\frac{\bar{\sigma}}{\bar{m}}$. of Wright (1959) that psoriasis and sero-positive $\widetilde{\Phi}_{\overparen{D}}$ R.A. are unrelated and that their occasional occurrence together is coincidental. Wright's conclusion ${ }^{\infty}$ was based on qualitative evidence and hitherto has $\vec{O}$ remained unsupported by quantitative data. $\overrightarrow{.}$ Psoriasis is found no more (and no less) commonly in $\omega_{\sigma}$ subjects with sero-positive "R.A." than in the population at large. It has also shown that there is no familial aggregation of the two diseases. of

On the other hand, psoriasis and sero-negative $\omega$ polyarthritis occur together too frequently for the N association to be due to chance. When the polyarthritis is of a certain pattern with predominant involvement of terminal finger joints, the association $\overrightarrow{\vec{z}}$ is almost constant but, even when such patients were removed from consideration, 9.6 per cent. of the remainder, with a joint disease indistinguishable $\mathscr{\odot}$ from that of sero-positive R.A., proved to have. psoriasis. This is at least five times the rate found in sero-positive propositi or controls and it thus appears that the association of psoriasis and sero-ō negative R.A. is of significance.

The family study has suggested an aggregation of $\stackrel{2}{\stackrel{D}{2}}$ psoriasis and sero-negative "R.A.". The numerical $\overrightarrow{\vec{O}}$ base is small and confirmation from larger popula- 3 tion studies is desirable. It should also be kept in mind that psoriasis was found in the siblings of onlyọ. six of 47 sero-negative propositi. It thus seems that only a small proportion, perhaps 10 per cent. of $\overline{0}$ such subjects, have psoriatic arthritis and are at risk $\frac{0}{3}$ of developing psoriasis in the future. The fact that psoriasis has been observed to supervene manyo years after the onset of arthritis is in keeping with this concept (Baker, Golding, and Thompson, 1963). 음

Summary

(1) The prevalence of psoriasis in a sample of 738 surgical in-patients at the London Hospital was N found to be 1.5 per cent.

(2) The prevalence of psoriasis in a sample of $407 \%$ patients with sero-positive rheumatoid arthritis was between $1 \cdot 2$ and $2 \cdot 0$ per cent. Thus, the occasionalassociation of the two diseases is likely to be due to $\stackrel{\mathcal{C}}{\rightarrow}$ chance.

(3) There was no familial aggregation of psoriasis and sero-positive rheumatoid arthritis, further ${ }_{\Omega}^{\mathbb{\Phi}}$ evidence that the diseases are unrelated. 
(4) In a sample of 104 patients with sero-negative polyarthritis of typically rheumatoid pattern, psoriasis was found in 9.6 per cent., a rate at least five times as high as in the sero-positive propositi and controls. The association of psoriasis and "sero-negative rheumatoid arthritis" cannot therefore be ascribed to chance.

(5) There was some familial aggregation of psoriasis and sero-negative rheumatoid arthritis. One of the factors determining the clinical association of these two diseases may therefore be a genetic one. A latent psoriatic genetic factor may be responsible for the persistent sero-negativity of a minority of patients with rheumatoid arthritis.

The subject matter of this paper formed part of the substance of a M.D. thesis submitted to the University of Leeds.

The author is grateful to the Arthritis and Rheumatism Council for financial support and to Drs. W. Tegner, R. M. Mason, B. Russell, and J. S. Pegum, and the surgeons of the London Hospital for permission to examine their patients. Dr. H. B. May made laboratory facilities available and Dr. J. A. Heady provided statistical advice. The author is particularly indebted to Dr. Mason for help, encouragement, and advice at all stages of the study.

\section{REFERENCES}

Baker, H., Golding, D. N., and Thompson, M. (1963). Ann. intern. Med., 58, 909.

Ball, J. (1950). Lancet, 2, 520.

Dixon, A. St. J. (1960). Ann. rheum. Dis., 19, 209.

Gribble, M. de G. (1955). Ibid., 14, 198.

Steinberg, A. G., Becker, S. W., Fitzpatrick, T. B., and Kierland, R. R. (1951). Amer. J. hum. Genet., 3, 267.

Wright, V. (1959). Amer. J. Med., 27, 454.

\section{APPENDIX I}

\section{Criteria for Selection of Arthritic Propositi}

\section{The Sero-positive Group}

Inclusion required five of the following criteria, the total duration of continuous joint symptoms being not less than 6 weeks. The 8 th criterion had to be fulfilled in all patients.

\section{Examined Propositi}

(1) Morning stiffness.

(2) Pain on motion or tenderness in at least one joint.

(3) Swelling (soft tissue thickening or fluid-not bony overgrowth alone) in at least one joint.

(4) Swelling of at least one other joint (any interval free of joint symptoms between the two joint involvements may not be more than 3 months).
(5)* Symmetrical joint swelling with simultaneous involvement of the same joint on both sides of the body (bilateral involvement of mid-phalangeal, metacarpophalangeal or metatarsophalangeal joints was acceptable without absolute symmetry).

(6) Subcutaneous nodules of rheumatoid type.

(7) $X$-ray changes typical of rheumatoid arthritis (which had to include at least bony decalcification localized to or greatest around the involved joints, and not merely degenerative changes)-degenerative changes did not exclude patients from the group of rheumatoid arthritis.

(8) Positive serological tests (S.C.A.T. titre 1:32 and latex titre $1: 80$ ).

(9) Characteristic histological changes in synovial membrane or nodules.

\section{Non-examined Propositi}

As above, but an S.C.A.T. titre of $1: 32$ or a latex titre of 1:160 satisfied the serological criterion.

\section{The Sero-negative Group}

Inclusion required seven of these criteria to be satisfied, 8 and 10 being obligatory.

\section{Examined Propositi}

Criteria 1 to 5,7 and 9 as above, plus: hr).

(6) Erythrocyte sedimentation rate raised $(>20 \mathrm{~mm}$./

(8) Total duration of joint symptoms not less than 2 years.

(10) No S.C.A.T. titre greater than 1:8 and no latex titre greater than $1: 20$.

\section{Non-eXamined Propositi}

Criteria 1 to 9 as for examined sero-negative propositi, plus:

(10) No S.C.A.T. titre greater than 1:8 or at least two latex titres no greater than 1:20 and no latex titre greater than this (if S.C.A.T. not done).

\section{APPENDIX II}

\section{Diagnosis OF PSORIASIS}

This diagnosis was a clinical one, made in all cases by the author. On the basis of his own clinical experience, discussion with colleagues, and two small formally arranged "observer variability tests" the following criteria were laid down for personal guidance:

(1) Psoriasis in the scalp must be palpable.

(2) Mild psoriasis of the scalp simulating dandruff

*Note that the 5 th criterion is a modification of the A.R.A. one. In this study terminal interphalangeal joint swelling (inflammatory) satisfied this criterion. 
must in addition show areas of completely uninvolved skin between the scaly patches.

(3) In the presence of eczema, seborrhoea corporis, or seborrhoeic dermatitis anywhere on the body, lesions other than classical ones on the scalp or elsewhere cannot be accepted as psoriasis.

(4) Toe-nail lesions alone cannot be accepted as evidence of psoriasis.

(5) Only classical finger-nail lesions of psoriasis, namely gross pitting, onycholysis, and the characteristic discoloration of the lateral aspects of the free ends of the nails, was accepted in the absence of unequivocal psoriasis elsewhere or a definite previous history of psoriasis and only after microscopy and culture of nail had excluded infection.

(6) Flexural lesions in the absence of psoriasis elsewhere are rare, and these were only accepted in the presence of other lesions or if classical, i.e. with a sharplydefined margin around the whole circumference of all the flexural lesions.

(7) Pustular dermatosis of the palms and soles, whether or not conforming to the published descriptions of "pustular psoriasis", was not accepted as psoriasis in the absence of other unequivocal lesions of the skin elsewhere or nails.

La fréquence du psoriasis chez des malades polyarthritiques et leurs familles

RÉSUMÉ

(1) On a trouvé que la fréquence du psoriasis parmi 738 malades chirurgicaux hospitalisés à London Hospital était de 1,5 pour cent.

(2) La fréquence du psoriasis dans un échantillon de 407 malades atteints d'arthrite rhumatismale séropositive était de 1,2 à 2 pour cent. Il s'en suit que l'association de ces deux maladies chez le même sujet est probablement fortuite.

(3) On n'a pas trouvé d'agrégation familiale du psoriasis et de l'arthrite rhumatismale séro-positive, ce qui montre une fois de plus l'absence de toute relation entre ces deux maladies.

(4) Dans un échantillon de 104 malades atteints de polyarthrite séro-négative à forme typiquement rhuma-? toïde on trouva le psoriasis en 9,6 pour cent, ce qui $\overrightarrow{\vec{F}}$ représente une fréquence cinq fois plus grande que chez $\stackrel{\oplus}{+}$ les sujets séro-positifs et les témoins. On ne peut donc믐 pas attribuer au hazard l'association du psoriasis et de $\bar{\sigma}$ l' "arthrite rhumatismale séro-négative".

(5) On a trouvé un certain degré d'agrégation familiale $\frac{\omega}{\vec{D}}$ du psoriasis et de l'arthrite rhumatismale séro-négative. $₫$ Un des facteurs déterminant l'association clinique de ces deux maladies peut donc être génétique. Un facteur ${ }^{\text {s }}$ génétique psoriasique latent peut être responsable de la $\vec{\circ}$ séro-négativité persistante d'une minorité de malades atteints d'arthrite rhumatismale.

La frecuencia de la psoríasis en enfermos poliartríticos y en
sus parientes
SUMARIO
(1) La frecuencia de la psoríasis en una muestra comprendiendo 738 enfermos quirúrgicos en el Londono Hospital fué de un 1,5 por ciento.

(2) La frecuencia de la psoriasis en una muestra de $407^{-}$ enfermos con artritis reumatoide sero-positiva fué de un 1,2 a 2 por ciento. La asociación de estas enfermedades, cuando ocurre, es pués accidental.

(3) La agregación familiar de la psoríasis y de la $\vec{\ominus}$ artritis reumatoide sero-positiva no fué encontrada, loo que confirma la ausencia de toda relación entre estas enfermedades.

(4) En una muestra de 104 enfermos con poliartritis sero-negativa presentando un cuadro reumatoide típico, $\bar{\partial}$ la psoríasis fué encontrada en un 9,6 por ciento, dandoฏ una frecuencia cinco veces mayor que la en los sujetos sero-positivos y en los testigos. Aquí, la asociación entre la psoríasis y la artritis reumatoide sero-negativa no $\overrightarrow{\vec{B}}$ se puede atribuir a la casualidad.

(5) Se encontró una cierta agregación familiar de la psoríasis y de la artritis reumatoide sero-negativa. Uno de los factores determinantes de la asociación clínica de estas dos enfermedades puede pues ser genético. Un⿳亠㐅冋 factor genético psoriásico latente puede llevar la res-̄̄ ponsabilidad de la sero-negatividad persistente de unaominoria de enfermos con artritis reumatoide. 